\title{
Regulatory Effect of Glucagon on its Own Receptor Concentrations and Target-Cell Sensitivity in the Rat
}

\author{
A. Santos ${ }^{1}$ and E. Blazquez ${ }^{2}$ \\ ${ }^{1}$ Instituto G. Marañon, Consejo Superior Investigaciones Cientificas, Madrid and \\ ${ }^{2}$ Departamento de Fisiologia, Facultad de Medicina, Universidad de Oviedo, Spain
}

Summary. To evaluate the role of glucagon on its hepatocyte receptor concentrations, groups of rats were injected with a long-acting glucagon preparation (20 [G-20], 40 [G-40] or 60 [G-60] $\mu \mathrm{g} / 100 \mathrm{~g}$ body weight) every $8 \mathrm{~h}$ for 4 days. Glucagon receptors in liver plasma membranes of treated animals were decreased in number (control $=1.66 \pm 0.20 \mathrm{ng} / 0.5 \mathrm{mg}$ protein versus $\mathrm{G}-20=1.24 \pm 0.26, \mathrm{G}-40=1.03 \pm 0.26, \mathrm{G}-60$ $=0.70 \pm 0.03 \mathrm{ng} / 0.5 \mathrm{mg}$ protein $; p<0.05,<0.001$, $<0.001$, respectively), but they were indistinguishable from receptors of control rats by other criteria including affinity and kinetics of association. Degradation of both glucagon and receptor sites did not account for differences observed in binding. Similar results were obtained with isolated hepatocytes. In relation to controls, isolated hepatocytes of treated rats had a reduced number of receptors (control $=0.70 \pm$ 0.05 versus $\mathrm{G}-40=0.47 \pm 0.04 \mathrm{ng} / 10^{6}$ cells $; p<$ 0.02 ) proportionate to the decreased glucagon-stimulated production of cyclic AMP and glucose. Four to eight hours exposure of cultured hepatocytes of nontreated rats to $4 \times 10^{-8} \mathrm{~mol} / \mathrm{l}$ glucagon produced a decreased binding of ${ }^{125} \mathrm{I}$-glucagon to its receptor $(p<0.05)$. In contrast, hormone exposure for shorter periods of time $(0-2 \mathrm{~h})$ was without effect. These results suggest (1) an inverse relationship between circulating glucagon levels and hepatocyte glucagon receptor concentration, and (2) a direct relation between receptor number and target-cell response.

Key words: Liver membranes, isolated rat hepatocytes, glucagon receptor concentrations, regulation by homologous hormone, modified target cell sensitivity, plasma glucagon, glucagon in rats, hepatic cyclic AMP.

Hormones may modify their own receptor number. This phenomenon, first described for insulin [1], has subsequently been shown for several other hormones [2-4].

In relation to glucagon, there is contradictory evidence concerning the role of this hormone in the regulation of its own receptors. Hyperglucagonaemia of fasted [5] and developing rats [6], and animals undergoing liver regeneration [7] is associated with a decrease of binding sites for glucagon in the liver. There is also a proportional reduction of glucagon-stimulated adenylate cyclase activity, whereas in the hyperglucagonaemic state observed in chronic renal failure of liver glucagon receptors are increased [8]. There is contradictory evidence concerning high circulating levels of glucagon found in diabetic animals; both increased [9] and decreased [10] binding of glucagon to liver membranes has been described. After the parenteral administration of exogenous glucagon, a decrease in the number of liver receptors for glucagon has been reported [10-12], but again it is not clear whether this modification is accompanied $[10,11]$ or not, by changes [12] in the glucagon-stimulated adenylate cyclase activities.

In view of the contradictory reports, an experimental model has been developed which would firstly permit the correlation of the effects of glucagon on (a) its receptor concentrations in the liver and (b) the relationship between glucagon receptor number and target-cell response and secondly elucidate whether the action of glucagon on its own receptors is due to a direct effect.

\section{Materials and Methods}

\section{Experimental Animals}

Male Wistar rats, weighing 120-150 g, were housed under constant conditions of lighting and temperature. Animals were fed on a standard diet (fat $3.8 \%$, carbohydrates $49.5 \%$, protein $21.4 \%$ ). The experimental groups of rats included: (1) three groups injected subcutaneously with different doses $(60 \mu \mathrm{g}, 40 \mu \mathrm{g}$ or $20 \mu \mathrm{g} / 100 \mathrm{~g}$ body 
weight) of long-acting glucagon (protamine-zinc-glucagon, Novo Industrias, Copenhagen), every $8 \mathrm{~h}$ (administered at $0800,1600 \mathrm{~h}$ and midnight) for a period of 4 days, and (2) a control group of rats which were injected subcutaneously with placebo (protaminezinc).

\section{Measurement of Immunoreactive Glucagon}

Overnight fasted control and glucagon-treated rats were anaesthetized with ether and blood samples were taken from the portal vein. The blood samples were collected in pre-chilled test tubes containing apronitin (Trasylol, FBA Pharmaceuticals, New York, $500 \mathrm{KIU} / \mathrm{ml})$ and EDTA $(1.2 \mathrm{mg} / \mathrm{ml})$, centrifuged at $4^{\circ} \mathrm{C}$ and the plasma was preserved frozen until analyzed. Blood plasma glucagon was determined by radioimmunoassay [13] with a C-terminal reactive antiglucagon serum $(30 \mathrm{~K})$ (generously donated by $\mathrm{Dr}$. R.H. Unger, Dallas). Sensitivity of the assay was up to and including $20 \mathrm{pg} / \mathrm{ml}$ and the percentage of intra- and inter-assay variation was 3 and $6 \%$ respectively.

\section{Preparation of Liver Plasma Membranes}

Livers from rats fasted overnight were taken immediately after post mortem. After removal, the livers were quickly minced and homogenized in $1 \mathrm{mmol} / 1 \mathrm{NaHCO}_{3}$ solution $(10 \mathrm{~g}$ in $500 \mathrm{ml}$ of $1 \mathrm{mmol} / \mathrm{l}$ $\mathrm{NaHCO}_{3}$ ) at $4^{\circ} \mathrm{C}$. Partially purified liver plasma membranes were prepared by the method of Neville [14] as modified by Pohl et al. [15] and stored in liquid nitrogen. To provide an index of membrane purification, binding of ${ }^{125} \mathrm{I}$-glucagon to its liver receptors and 5'nucleotidase activity [16] were determined in the whole liver homogenate, the $1500 \mathrm{~g}$ pellet and the partially purified liver membranes. Membrane protein was determined by the method of Lowry et al. [17].

\section{Isolation of Hepatocytes}

Isolated hepatocytes were prepared from normal and glucagontreated rats fasted overnight. The animals were anaesthetized with ether, the abdomen opened through a wide incision and the portal vein exposed and cannulated. The liver was then perfused with $120 \mathrm{ml}$ of calcium and magnesium-free Krebs Ringer bicarbonate buffer ( $\mathrm{pH}$ 7.4) for $4 \mathrm{~min}$. Another $150 \mathrm{ml}$ of perfusion medium with $40 \mathrm{mg}$ of collagenase type I (160 units/mg; Sigma Chemicals, St. Louis, USA) were infused into the liver for $5 \mathrm{~min}$. At the end of the perfusion period, the liver was removed, cut into fine pieces and incubated with Krebs Ringer bicarbonate buffer (pH 7.4) and $10 \mathrm{~g} / 1$ bovine serum albumin at $37^{\circ} \mathrm{C}$ with slow stirring for $5 \mathrm{~min}$. The digested liver was filtered and the cells spun down at $50 \mathrm{~g}$ for $2 \mathrm{~min}$. All procedures with isolated cells and liver membranes were carried out in plastic laboratory ware. Cell number was determined by counting in a Neubauer chamber. Cell size was measured after determining the cell diameter of hepatocytes (at least 50 cells were evaluated in each cell suspension) visualized with a phase contrast microscope.

\section{Tests of Hepatocyte Viability}

Biochemical and morphological approaches were used in order to test cell viability. Trypan blue exclusion was determined by the ability of hepatocytes to exclude $0.5 \%(\mathrm{w} / \mathrm{v})$ of the stain in the absence of albumin for $2 \mathrm{~min}$. Ultrastructure of the isolated hepatocytes was studied with the electron microscope [18]. The adenosine triphosphate (ATP) content of the cells was determined by the method of Williamson and Corkey [19].
Binding of glucagon to their hepatocyte receptors and cyclic AMP production in the absence or presence of different glucagon concentrations were also determined. The rate of gluconeogenesis was measured by assaying the glucose content in the incubation buffer immediately after the cell suspension was added and at different times thereafter $(0-2 \mathrm{~h})$.

\section{Iodination of Glucagon and Insulin}

Mono- ${ }^{125}$ I-glucagon was obtained according to the procedure of Nottey and Rosselin [20] with specific activities of $450-500 \mu \mathrm{Ci} / \mu \mathrm{g}$. Iodination was carried out in at a total volume of $100 \mu \mathrm{lof} 0.3 \mathrm{~mol} / \mathrm{l}$ phosphate buffer ( $\mathrm{pH} 7.4$ ) containing $5 \mu \mathrm{g}$ porcine glucagon (Novo Industrias, Copenhagen), $2.5 \mathrm{mCi}$ of ${ }^{125} \mathrm{I}-\mathrm{Na}$ and chloramine-T $(25 \mu \mathrm{g})$ for $30 \mathrm{~s}$. This was immediately followed by the addition of sodium metabisulphite $(50 \mu \mathrm{g})$ and $100 \mu \mathrm{l}$ of $0.3 \mathrm{~mol} / \mathrm{l}$ phosphate buffer ( $\mathrm{pH}$ 7.4) with $10 \mathrm{~g} / 1$ bovine serum albumin. Trichloroacetic acid precipitability or talc adsorption of the iodinated hormone was $80 \%-90 \%$. The reaction mixture was applied to a $0.9 \times 30 \mathrm{~cm}$ DEAE cellulose column (Whatman 52) equilibrated with $0.05 \mathrm{~mol} / 1 \mathrm{Tris}-\mathrm{HCl}$ and $7 \mathrm{~mol} / 1$ urea $(\mathrm{pH} 9.3)$ at $4^{\circ} \mathrm{C}$. After the passage of $80 \mathrm{ml}$ of the same buffer, a linear gradient of $\mathrm{NaCl}$ from 0 to $0.2 \mathrm{~mol} / 1$ was run. Mono-iodinated hormone obtained after column chromatography was dialyzed against $0.3 \mathrm{~mol} / \mathrm{l}$ phosphate buffer ( $\mathrm{pH} \mathrm{7.5)}$ and immediately stored at $-20^{\circ} \mathrm{C}$. With a similar procedure, porcine insulin monocomponent (Novo Research Institute, Denmark) was iodinated with $\mathrm{Na}^{125}$ I (Radiochemical Centre, Amersham, Bucks, UK) to yield specific activities of $240-300 \mu \mathrm{Ci}$ / $\mu \mathrm{g}$. Mono- ${ }^{125}$-I-insulin was obtained after the iodinated mixture was chromatographied on DEAE cellulose column $(0.9 \times 30 \mathrm{~cm}$, Whatman 52) with 0.05 mol/1 Tris- $\mathrm{HCl}(\mathrm{pH} 9.3)$ and a linear gradient of $\mathrm{NaCl}(0-0.1 \mathrm{~mol} / \mathrm{l})$.

\section{Measurement of Hormone Binding to Liver Membranes and Isolated Hepatocytes}

The binding to liver membranes of mono-iodinated hormone was carried out as described by Rubalcava and Rodbell [21]. Liver membranes $(100-200 \mu \mathrm{g}$ of protein $/ \mathrm{ml})$ were incubated with Krebs Ringer phosphate buffer ( $\mathrm{pH} 7.5)(\mathrm{NaCl}: 118 \mathrm{mmol} / 1, \mathrm{KCl}$ : $5 \mathrm{mmol} / 1, \mathrm{MgSO}_{4}: 1.2 \mathrm{mmol} / 1, \mathrm{KH}_{2} \mathrm{PO}_{4}: 1.2 \mathrm{mmol} / 1, \mathrm{Na}_{2} \mathrm{HPO}_{4}$ : $10 \mathrm{mmol} / \mathrm{l}, 10 \mathrm{~g} / \mathrm{l}$ bovine serum albumin and mono ${ }^{125} \mathrm{I}$-glucagon $\left(5 \times 10^{-11} \mathrm{~mol} / \mathrm{l}\right)$ ) at $10^{\circ} \mathrm{C}$ or $20^{\circ} \mathrm{C}$ for $0-9 \mathrm{~h}$, unless otherwise indicated. At the end of the incubation periods, the samples were diluted out rapidly in Krebs Ringer phosphate buffer ( $\mathrm{pH} 7.5)$ with $1 \mathrm{ml}$ of ice-chilled solution of $10 \mathrm{~g} / \mathrm{l}$ albumin and immediately filtered on oxoid filters $(0.45 \mu \mathrm{m})$ soaked in $100 \mathrm{~g} / 1$ albumin for $30 \mathrm{~min}$ before use. To correct for non-specific adsorption of the peptides to liver membranes, the binding of radioactive hormone was determined in the presence of $1 \times 10^{-6} \mathrm{~mol} / 1$ unlabelled glucagon, a concentration which would more than saturate specific hormone-binding sites. The difference between membrane-bound radioactivity in the absence or presence of an excess of unlabelled hormone was considered to represent binding of labelled hormone to specific binding sites. Radioactivity was determined in a welltype scintillation counter. The same experimental procedure was followed in the binding studies with isolated hepatocytes except that Krebs Ringer bicarbonate buffer ( $\mathrm{pH} \mathrm{7.4),} \mathrm{was} \mathrm{used} \mathrm{as} \mathrm{the} \mathrm{in-}$ cubation medium.

Hormone degradation was studied after the incubation of ${ }^{125} \mathrm{I}$ glucagon $\left(1 \times 10^{-10} \mathrm{~mol} / \mathrm{l}\right)$ with liver membranes $(0.13 \mathrm{mg} / \mathrm{ml})$ or isolated hepatocytes $\left(16^{6}\right.$ cells $\left./ \mathrm{ml}\right)$ and Krebs Ringer buffer containing albumin $(10 \mathrm{~g} / 1)$ for the indicated times. The supernatant then was removed and the percentage of counts that bound to fresh liver membranes during a subsequent period of incubation was de- 
termined. Tubes incubated under identical conditions without liver membranes or cells in the first incubation served as controls. The percentage of hormone degraded was calculated, as a function of the control by comparing the percentage of counts of ${ }^{125}$ I-glucagon that bound to liver membranes or isolated hepatocytes during the first incubation and after the second one with fresh liver membranes. Glucagon receptor degradation by liver membranes of control and glucagon-treated rats was studied as a function of time and temperature. Liver membranes $(0.15 \mathrm{mg} / \mathrm{ml})$ were pre-incubated in tubes containing Krebs Ringer phosphate $(\mathrm{pH} 7.5)$ and albumin $(10 \mathrm{~g} / \mathrm{l})$ at $10^{\circ} \mathrm{C}$ or $20^{\circ} \mathrm{C}$ for the indicated times. The tubes were then equilibrated in a $20^{\circ} \mathrm{C}$ water bath and ${ }^{125} \mathrm{I}$-glucagon was added. In a second set, unlabelled glucagon $\left(1 \times 10^{-6} \mathrm{~mol} / \mathrm{l}\right)$ was also added to measure non-specific binding. Incubations were carried out at $20^{\circ} \mathrm{C}$ for $90 \mathrm{~min}$. The specific ${ }^{125} \mathrm{I}$-glucagon binding was expressed as a percentage of the binding observed with no pre-incubation.

\section{Glucagon-Stimulated Glucose and Cyclic AMP Production by Rat Hepatocytes}

Isolated hepatocytes $\left(2 \times 10^{6}\right.$ cells $\left./ \mathrm{ml}\right)$ were incubated with Krebs Ringer bicarbonate ( $\mathrm{pH} 7.4)(\mathrm{NaCl}: 120 \mathrm{mmol} / 1, \mathrm{KCl}: 4.8 \mathrm{mmol} / \mathrm{l}$, $\mathrm{CaCl}: 1.3 \mathrm{mmol} / 1, \mathrm{KH}_{2} \mathrm{PO}_{4}: 1.2 \mathrm{mmol} / \mathrm{l}, \mathrm{MgSO}_{4}: 1.2 \mathrm{mmol} / 1$, $\mathrm{NaHCo}_{3}: 24 \mathrm{mmol} / \mathrm{l}$ ) containing $40 \mathrm{~g} / 1$ bovine serum albumin (BSA), alanine $(10 \mathrm{mmol} / \mathrm{l})$ and in the presence $\left(5.5 \times 10^{-7} \mathrm{mmol} / \mathrm{l}\right)$ or absence of glucagon and cyclic AMP $(0.8 \mathrm{mmol} / 1)$.

Cell suspensions were gassed with $95 \%$ oxygen $/ 5 \%$ carbon dioxide, and incubated with gentle shaking at $37^{\circ} \mathrm{C}$. The fraction $\mathrm{V}$ bovine albumin powder was defatted before use by the procedure of Guillory and Racker [22]. At the end of the incubation period, the samples were chilled in an ice bath, centrifuged and aliquots of the medium taken for glucose assay by the glucose oxidase method [23].

In those experiments in which cyclic AMP production by hepatocytes was studied, the incubation medium was supplemented with $2 \mathrm{mmol} / 1$ theophylline, and glucagon was added in a broad concentration range from 0 to $10^{-6} \mathrm{~mol} / \mathrm{l}$. Cyclic AMP accumulation was increased by glucagon with a maximal effect at $2.5 \mathrm{~min}$, the values decreasing almost to basal levels by $20 \mathrm{~min}$. At 60 and 120 min of incubation, cyclic AMP values were indistinguishable from basal concentrations. Therefore, $2.5 \mathrm{~min}$ incubation periods were selected to study the glucagon-stimulated cyclic AMP production. After 2.5 min of incubation, cell suspensions were treated with trichloacetic acid ( $5 \%$ final concentration, w/v), centrifuged and the supernatant washed with ether saturated with water. In aliquots of the aqueous phase, cyclic AMP was assayed by radioimmunoassay as described by Steiner et al. [24]. Sensitivity of the assay was up to and including $0.2 \mathrm{pmol}$ and the percentage of intraand inter-assay variation were of 4 and $8 \%$, respectively.

\section{Pre-Incubation of Hepatocytes with Glucagon}

Isolated hepatocytes from control rats were incubated at $37^{\circ} \mathrm{C}$ in a 199 medium (Gibco Bio-Cult) supplemented with $10 \mathrm{~g} / \mathrm{I}$ bovine serum albumin, penicillin and streptomycin $(2000 \mathrm{U}$ and $2 \mathrm{mg} / \mathrm{ml}$, respectively) for $0-8 \mathrm{~h}$ in the presence $\left(4 \times 10^{-8} \mathrm{~mol} / 1\right)$ or absence of glucagon.

\section{Washing Procedure Before ${ }^{125}$ I-Glucagon Binding}

After pre-incubation, aliquots of cell suspensions were transfered to plastic centrifuge tubes containing $2 \mathrm{ml}$ of Krebs Ringer bicarbonate and spun at $50 \mathrm{~g}$ for $2 \mathrm{~min}$. Cells were immediately resus- pended in $3 \mathrm{ml}$ of Krebs Ringer bicarbonate, BSA $10 \mathrm{~g} / 1$ and incubated at $37^{\circ} \mathrm{C}$ for $30 \mathrm{~min}$. This incubation time was expected to be long enough to dissociate all the glucagon molecules bound to receptors during the pre-incubation period. In order to demonstrate this, aliquots of hepatocytes previously incubated without glucagon, were incubated at $37^{\circ} \mathrm{C}$ for $10 \mathrm{~min}$ with glucagon $\left(1 \times 10^{-7} \mathrm{~mol} / \mathrm{l}\right)$, and it was found, using the above procedure that the hormone dissociates immediately afterwards. No differences in ${ }^{125}$ I-glucagon binding to cells previously incubated with or without glucagon $\left(1 \times 10^{-7} \mathrm{~mol} / \mathrm{l}\right)$ were found.

\section{${ }^{125}$ I-Glucagon Binding to Washed Cells}

For binding studies, ${ }^{125}$ I-glucagon was incubated with washed cells $\left(5 \times 10^{5}\right)$ in a total volume of $0.5 \mathrm{ml}$ at $20^{\circ} \mathrm{C}$ in the presence or absence of $10^{-6} \mathrm{~mol} / 1$ glucagon. After $20 \mathrm{~min}$ of incubation, the cells were separated from the assay buffer by microfiltration. The radioactivity bound to cells in the presence of $1 \times 10^{-6} \mathrm{~mol} / 1$ glucagon was considered non-specific binding and was subtracted from total binding.

\section{Statistical Analysis}

Results have been expressed as mean \pm SEM. For statistical comparisons Student's t-test was used.

\section{Results}

In control rats the blood plasma glucagon levels in the portal vein (control $=360 \pm 63 \mathrm{pg} / \mathrm{ml} ; n=10$ ) were significantly smaller $(p<0.01)$ than those found in rats treated with 20,40 or $60 \mu \mathrm{g}$ of protamine-zincglucagon $/ 100 \mathrm{~g}$ body weight per $8 \mathrm{~h}$ during 4 days $(\mathrm{G}-20=850 \pm 160 ; \mathrm{G}-40=1200 \pm 400 ; \mathrm{G}-60=$ $2,800 \pm 515 \mathrm{pg} / \mathrm{ml} ; n=10)$. Glucagon levels in the portal vein of glucagon-treated rats were within the range obtained in non-treated animals after a physiological stimulus.

No statistically significant differences of 5 'nucleotidase activity and protein yield at the different stages of the purification procedure of liver plasma membranes were found between control and glucagon-treated rats. Thus, the total protein content in liver homogenates, was control $=2011 \pm 72, \mathrm{G}-20$ $=2200 \pm 115, \mathrm{G}-40=+2040 \pm 115$ and $\mathrm{G}-60=$ $1947 \pm 107 \mathrm{mg} / 10 \mathrm{~g}$ wet tissue. A similar protein content was obtained in the partially purified liver membranes of control (14 $\pm 2 \mathrm{mg}$ ) and of rats pre-treated with $20 \mu \mathrm{g}(10 \pm 11 \mathrm{mg}) 40 \mu \mathrm{g}(12 \pm 1 \mathrm{mg})$ and $60 \mu \mathrm{g}$ (13 $\pm 2 \mathrm{mg}$ ) of protamine-zinc-glucagon $/ 100 \mathrm{~g}$ body weight per $8 \mathrm{~h}$. On the other hand, $5^{\prime}$-nucleotidase activities ( $\mu \mathrm{mol} 5^{\prime} \mathrm{AMP}$ hydrolized $/ \mathrm{mg}$ protein $\mathrm{per} \mathrm{h}$ ) in liver homogenates were control $=1.5 \pm 0.3, \mathrm{G}-20=$ $1.8 \pm 0.3, \mathrm{G}-40=1.6 \pm 0.3, \mathrm{G}-60=1.5 \pm 0.3$, and in the partially purified liver membranes, control $=$ $14.2 \pm 1.8, \mathrm{G}-20=17.0 \pm 2.0, \mathrm{G}-40=14.5 \pm 1.8$, $\mathrm{G}-60=12.0 \pm 1.7$, with a purification factor of 9.5 , 


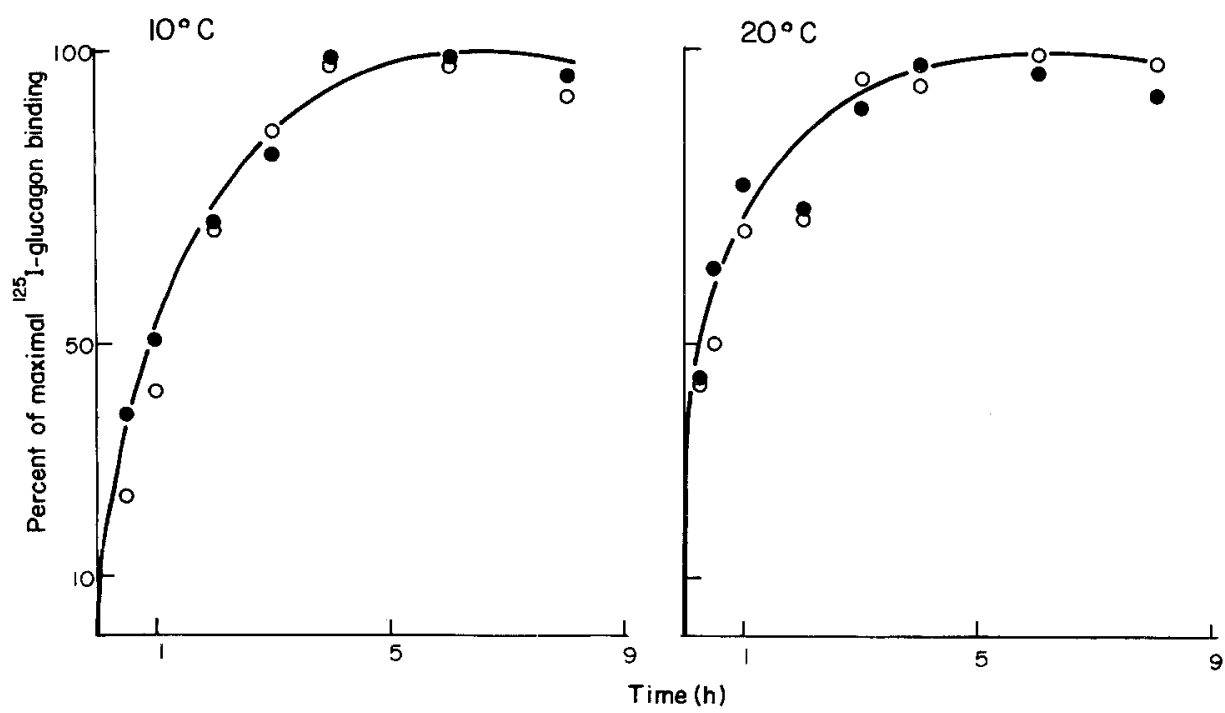

Fig. 1. Time course of association of glucagon liver membranes. ${ }^{125} \mathrm{I}$-glucagon was incubated with liver membranes from control $(0.12 \mathrm{mg} /$ $\mathrm{ml}$ ) and glucagon-treated rats $(0.10 \mathrm{mg} / \mathrm{ml})$ at $10^{\circ} \mathrm{C}$ or $20^{\circ} \mathrm{C}$. The specific ${ }^{125} \mathrm{I}$-glucagon binding was determined and plotted as the percentage of maximal ${ }^{125} \mathrm{I}$-glucagon binding. The single solid line approximates the time course for both control ( $\bullet$ and glucagon-treated rats $(40 \mu \mathrm{g} / 100 \mathrm{~g}$ body weight per $8 \mathrm{~h})\left(\begin{array}{ll}\mathrm{O} & \mathrm{O}\end{array}\right)$. The points are the mean of data obtained with liver membranes of three different rats. Percentage of variation interassay ranges from 2.5 to 10

Table 1. Glucagon binding during purification of liver membrane from control and glucagon-treated rats

\begin{tabular}{|c|c|c|c|c|}
\hline \multirow{3}{*}{$\begin{array}{l}\text { Purification } \\
\text { fraction }\end{array}$} & \multicolumn{4}{|c|}{ Glucagon binding ( $\mathrm{fmol} / \mathrm{mg}$ protein) } \\
\hline & \multirow{2}{*}{$\begin{array}{l}\text { Control } \\
\text { rats }\end{array}$} & \multicolumn{3}{|c|}{ Glucagon-treated rats } \\
\hline & & $\begin{array}{l}20 \mu \mathrm{g} \\
\text { (glucagon }\end{array}$ & $\begin{array}{l}40 \mu \mathrm{g} \\
100 \mathrm{~g} \text { body } \mathrm{x}\end{array}$ & $\begin{array}{l}60 \mu \mathrm{g} \\
\text { ight per } 8 \mathrm{~h} \text { ) }\end{array}$ \\
\hline $\begin{array}{l}\text { Dilute } \\
\text { homogenate } \\
\text { First }\end{array}$ & $2.4 \pm 0.4$ & $1.4 \pm 0.4$ & ND & ND \\
\hline $\begin{array}{l}\text { Sediment } \\
\text { Floated } \\
\text { particles }\end{array}$ & $16.2 \pm 1.7$ & $9.0 \pm 0.9$ & $8.0 \pm 1.1$ & $4.8 \pm 0.8$ \\
\hline
\end{tabular}

Results expressed as mean $\pm \operatorname{SEM}(n=10)$ ND: not detected

a See Methods for definition of purification fractions

9.4, 9.1 and 8 in the control, G-20, G-40 and G-60 groups, respectively. Hovever, at every step in the purification, there was less glucagon binding (Table 1) by the liver fraction of glucagon treated rats. Binding decreased progressively with increasing pre-treatment dose of protamine-zinc-glucagon.

To assess the kinetic properties of the glucagon receptors of the liver membranes from control and glucagon-treated rats $(40 \mu \mathrm{g} / 100 \mathrm{~g}$ body weight per $8 \mathrm{~h}$ ), association of the ${ }^{125}$-I-glucagon with both types of membranes were compared at $20^{\circ} \mathrm{C}$ and $10^{\circ} \mathrm{C}$ (Fig.1). When maximal binding of ${ }^{125}$-I-glucagon to both kinds of membranes was normalized, the time courses of association were similar. Maximum binding occurred at $4 \mathrm{~h}$ both at $10^{\circ} \mathrm{C}$ and at $20^{\circ} \mathrm{C}$.
Figure 2 shows that when the percentage of ${ }^{125} \mathrm{I}-$ glucagon bound to the liver membranes of control and glucagon pre-treated animals was plotted as a function of glucagon concentration, a significant reduction in the glucagon binding to the liver membranes of the experimental groups was observed compared with the control group over the range of 0.2 to $1000 \mathrm{ng} / \mathrm{ml}$. This decreased ${ }^{125} \mathrm{I}$-glucagon binding was proportional to the protamine-zinc-glucagon ( 20 , 40 or $60 \mu \mathrm{g} / 100 \mathrm{~g}$ body weight per $8 \mathrm{~h}$ ) dose previously injected to the different groups of rats. The bound to free ratio of the labelled hormone was also plotted as a function of bound hormone concentration according to Scatchard. Identically shaped parallel curves were obtained in all cases $(p>0.05)$. The calculated total number of binding sites (in $\mathrm{ng} / 0.5 \mathrm{mg}$ protein) was significantly greater in control $(1.66 \pm 0.20)$ than in pre-treated rats with $20 \mu \mathrm{g}$ $(1.24 \pm 0.26 ; p<0.05), 40 \mu \mathrm{g}(1.03 \pm 0.26 ; p<0.001)$ and $60 \mu \mathrm{g}(0.70 \pm 0.03 ; p<0.001)$ of protamine-zincglucagon $/ 100 \mathrm{~g}$ body weight per $8 \mathrm{~h}$, respectively.

Direct measurement of glucagon degradation suggested that it is a very rapid process, which is dependent on temperature $\left(10^{\circ} \mathrm{C}\right.$ and $\left.20^{\circ} \mathrm{C}\right)$ and incubation time $(0-7 \mathrm{~h})$. However, the same degradation rate of glucagon by liver membranes of control and glucagon pre-treated rats $(40 \mu \mathrm{g}$ of protamine-zincglucagon $/ 100 \mathrm{~g}$ body weight per $8 \mathrm{~h}$ ) was observed ( $p$ $>0.05)$. The increase in degradation of the receptor was a function of temperature $\left(10^{\circ}\right.$ and $\left.20^{\circ} \mathrm{C}\right)$ and time of incubation $(0-7 \mathrm{~h})$ and no differences were 

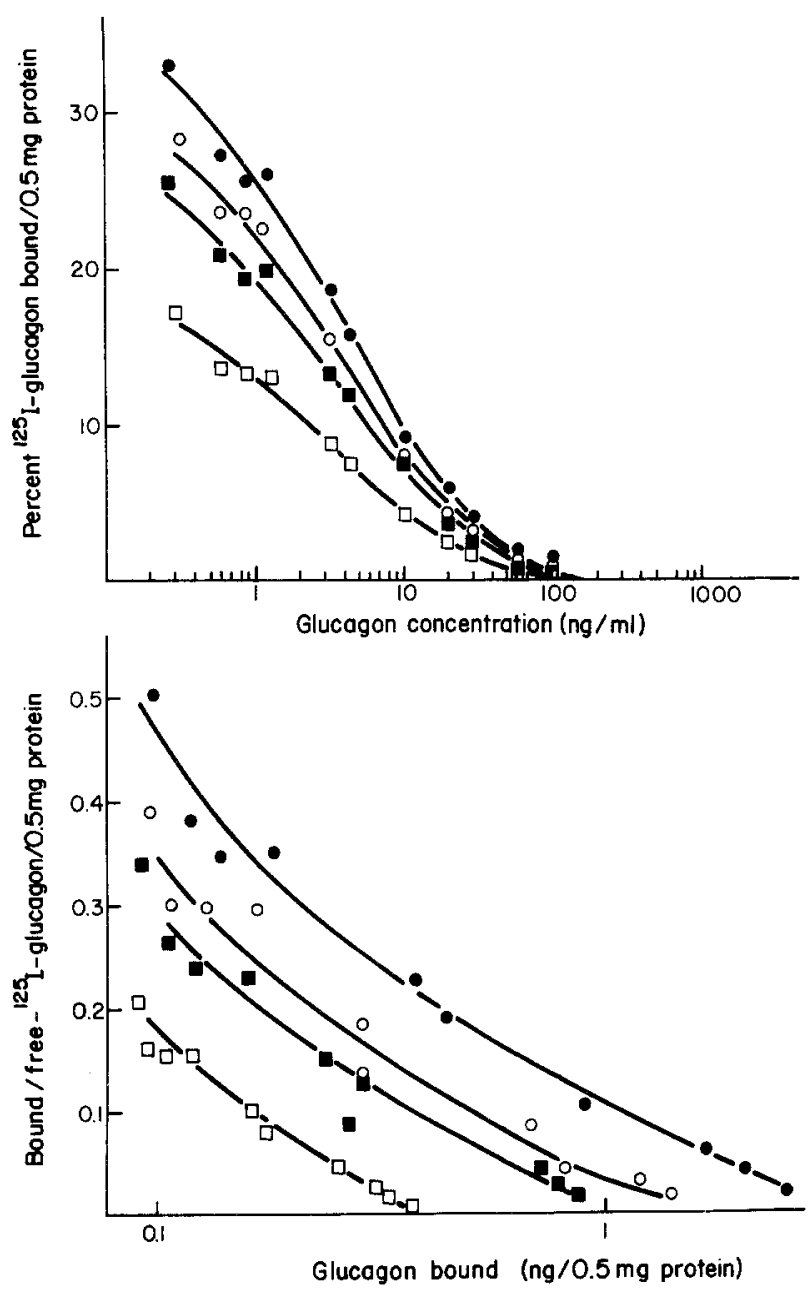

Fig. 2. Competition curves and Scatchard analysis of glucagon binding to liver membranes of $\operatorname{control}(\bullet)$ and glucagon-treated rats $(60 \mu \mathrm{g} \square \quad \square, 40 \mu \mathrm{g} \quad \square$ or $20 \mu \mathrm{g} \mathrm{O} \quad \mathrm{O} / 100 \mathrm{~g}$ body weight per $8 \mathrm{~h})$. Liver membranes $(0.15 \mathrm{mg} / \mathrm{ml})$ were incubated with Krebs Ringer phosphate ( $\mathrm{pH} 7.5)$ containing albumin $(10 \mathrm{~g} /$ $1),{ }^{125} \mathrm{I}$-glucagon $(0.28 \mathrm{ng} / \mathrm{ml})$ and in the absence or presence of unlabelled glucagon (from 0.3 to $1000 \mathrm{ng} / \mathrm{ml}$ ) at $20^{\circ} \mathrm{C}$ for $4 \mathrm{~h}$. Each point represents the mean of data obtained with liver membranes of five different rats

found between both groups of liver membranes ( $p>$ 0.05).

When the percentage of ${ }^{125} \mathrm{I}$-insulin bound to liver membranes (at $20^{\circ} \mathrm{C} 4 \mathrm{~h}$ incubation) of control and glucagon-treated rats $(40 \mu \mathrm{g} / 100 \mathrm{~g}$ body weight per $8 \mathrm{~h}$ ) was plotted as a function of insulin concentration (from 0.3 to $1000 \mathrm{ng} / \mathrm{ml}$ ), there was no difference in the two groups in binding of insulin to liver membranes $(p>0.05)$.

Hepatocytes were isolated from livers of control and glucagon-treated rats ( $40 \mu \mathrm{g}$ protamine-zinc-glucagon $/ 100 \mathrm{~g}$ body weight per $8 \mathrm{~h}$ ). The cell suspension was predominantly free hepatocytes, which were $80 \%$ viable as judged by their ability to exclude $5 \mathrm{~g} / 1$ trypan blue in the absence of albumin for $2 \mathrm{~min}$. These

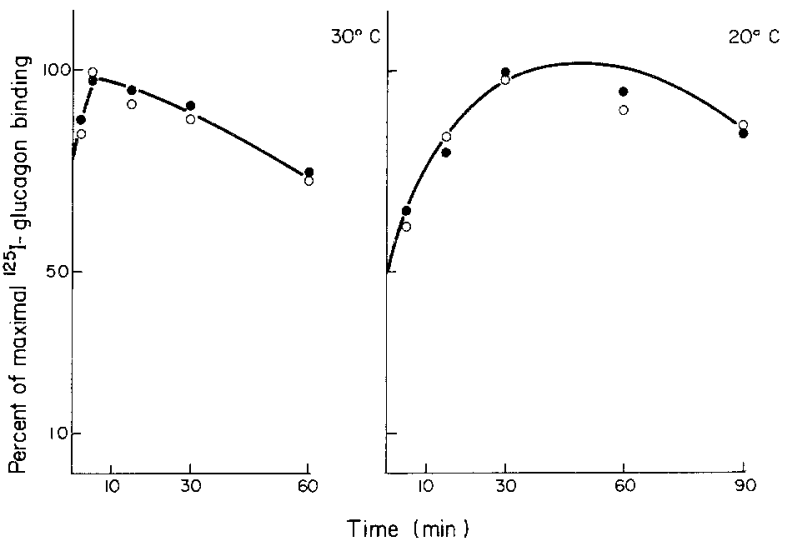

Fig. 3. Time course of association of glucagon to isolated hepatocytes. ${ }^{125} \mathrm{I}$-glucagon $\left(0.9 \times 10^{-10} \mathrm{~mol} / \mathrm{l}\right)$ was incubated with isolated hepatocytes $\left(1 \times 10^{6}\right.$ cells $\left./ \mathrm{ml}\right)$ in Krebs Ringer bicarbonate (pH 7.4), containing $10 \mathrm{~g} / \mathrm{l}$ albumin for the times and the temperatures indicated $(-)$ ) control rats; $(O \quad O)$ glucagon-treated rats $(40 \mu \mathrm{g} / 100 \mathrm{~g}$ body weight per $8 \mathrm{~h})$. Each value represents the mean of the data obtained with hepatocytes of five different rats. Percentage of variation interassay ranges from 3 to 9

cells were shown to be metabolically active and sensitive to glucagon. Their structures were also very well preserved as observed by electron microscopy. The liver cells obtained from both experimental groups consisted of about $90 \%$ hepatocytes. Mean cell diameter was almost the same in overnight fasted control $(24 \pm 0.1 \mu \mathrm{m} ; n=6)$ and glucagon-treated $(23.4 \pm 0.1 \mu \mathrm{m} ; n=6)$ rats. The isolated hepatocytes retained their ability to bind glucagon, increase the rate of gluconeogenesis from alanine over $2 \mathrm{~h}$ incubation period and augment the production of cyclic AMP proportionately to the amount of glucagon added to the incubation medium. The ATP content of these cells was $12.4 \pm 0.4 \mathrm{nmol} / \mathrm{mg}$ protein $\left(39.3 \pm 0.8 \mathrm{nmol} / 10^{6}\right.$ cells). These results are similar to those reported by others [25].

As shown in Figure 3, maximum binding of ${ }^{125} \mathrm{I}-$ glucagon to isolated hepatocytes was obtained with $10 \mathrm{~min}$ of incubation at $30^{\circ} \mathrm{C}$, compared with at $30 \mathrm{~min}$ at $20^{\circ} \mathrm{C}$. The time courses of association of ${ }^{125}$ I-glucagon to both kinds of hepatocytes when normalized to the maximal binding were indistinguishable up to $30 \mathrm{~min}$ at $20^{\circ} \mathrm{C}$ or $10 \mathrm{~min}$ at $30^{\circ} \mathrm{C}$. After the maximal binding was reached, the specific binding of ${ }^{125} \mathrm{I}$-glucagon began to decrease.

In contrast with the results obtained with liver membranes, the dissociation of ${ }^{125}$-I-glucagon from isolated hepatocytes (Fig. 4) was significantly accelerated by dilution of the incubation mixture or by the addition of unlabelled glucagon.

When the percentage of ${ }^{125} \mathrm{I}$-glucagon that was bound by the cells was plotted as a function of glucagon concentration (Fig.5), a decrease in the glucagon 

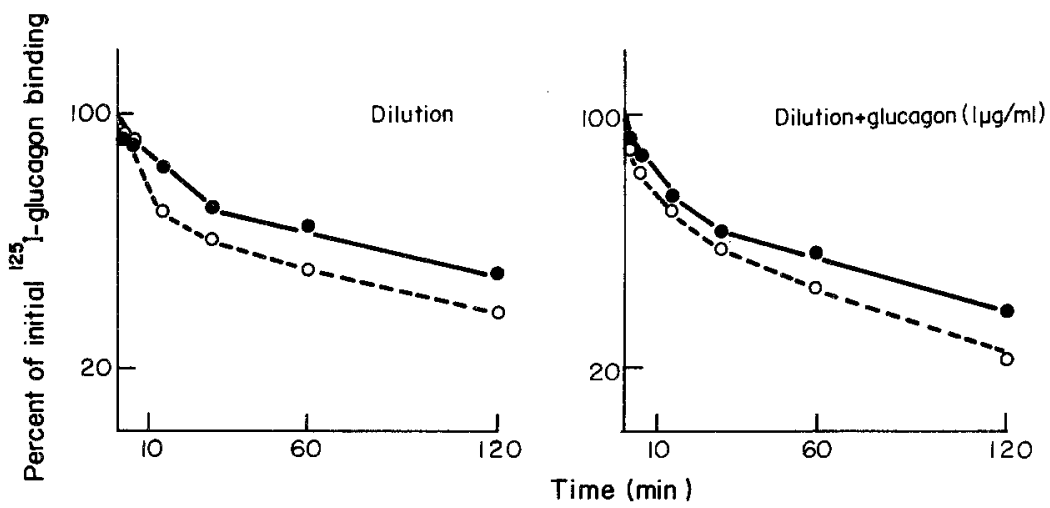

Fig. 4. Dissociation of ${ }^{125}$ I-glucagon from isolated hepatocytes of control (

) and glucagon-treated rats $(40 \mu \mathrm{g} / 100 \mathrm{~g}$ body weight per $8 \mathrm{~h})(\mathrm{O} O)$. Dissociation was performed after hepatocytes $\left(2 \times 10^{6}\right.$ cells $\left./ \mathrm{ml}\right)$ had been incubated with Krebs Ringer bicarbonate $(\mathrm{pH} 7.4),{ }^{125} \mathrm{I}$-glucagon $\left(10^{-10} \mathrm{~mol} / \mathrm{l}\right)$ and albumin $(10 \mathrm{~g} / 1)$ at $20^{\circ} \mathrm{C}$ for $30 \mathrm{~min}$. Then hepatocytes were washed with Krebs Ringer bicarbonate (pH 7.4) containing albumin $(10 \mathrm{~g} / \mathrm{l})$ and centrifuged at $50 \mathrm{~g}$ for $5 \mathrm{~min}$. The sediment was resuspended in the same buffer (three times more diluted; $0.66 \times 10^{6}$ cells $\left./ \mathrm{ml}\right)$ in the presence $(1 \mu \mathrm{g} / \mathrm{ml})$ or absence of unlabelled glucagon and incubated for the times indicated at $20^{\circ} \mathrm{C}$. The total ${ }^{125}$ I-glucagon binding with the non-specific binding substracted, was determined and plotted as the percentage of the initial ${ }^{125} I_{-}$ glucagon binding. The points represent the mean of data obtained with hepatocytes of three different rats. Percentage of variation interassay ranges from 2 to 8

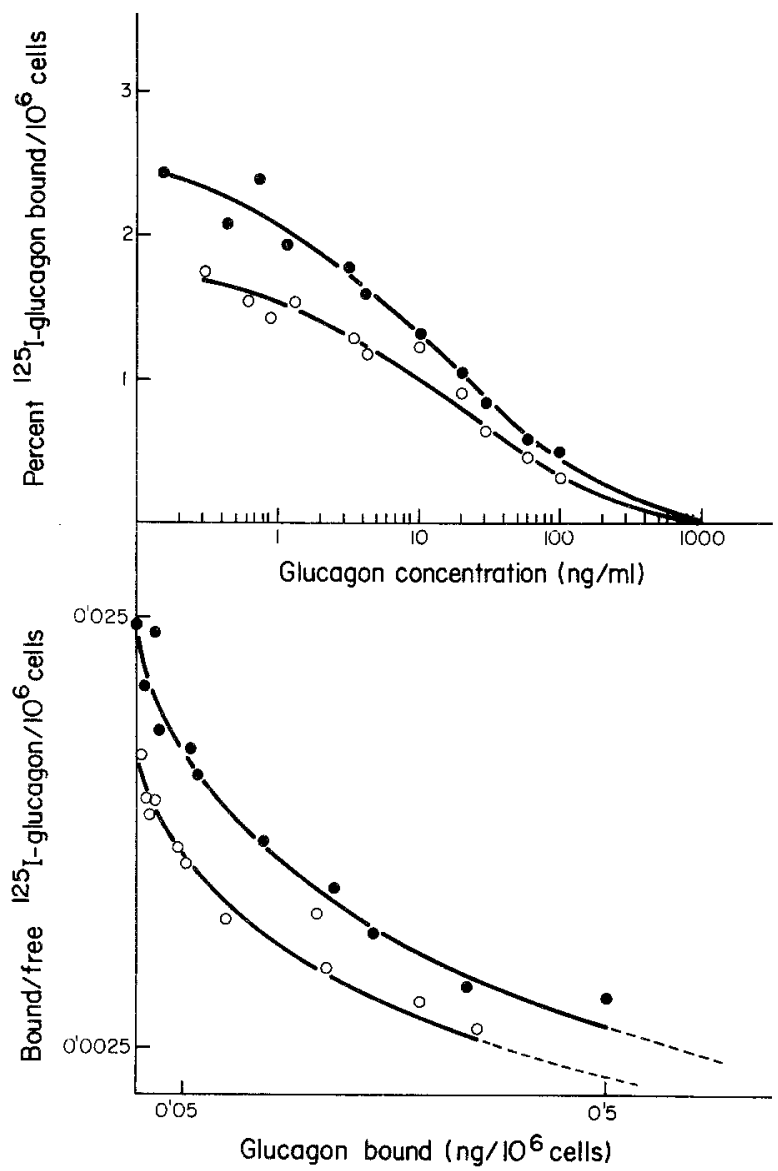

Fig.5. Competition curves and Scatchard analysis of glucagon binding to isolated hepatocytes of control $\left(-\frac{0}{0}\right)$ and glucagon-treated rats $(40 \mu \mathrm{g} / 100 \mathrm{~g}$ body weight per $8 \mathrm{~h})(\mathrm{O}$. O). Hepatocytes $\left(1 \times 10^{6}\right.$ cells $\left./ \mathrm{ml}\right)$ were incubated with Krebs Ringer bicarbonate $(\mathrm{pH} 7.4)$, containing albumin $(10 \mathrm{~g} / \mathrm{l}),{ }^{125}$ I-glucagon $\left(0.6 \times 10^{-10} \mathrm{~mol} / \mathrm{l}\right)$ and in the absence or presence of unlabelled glucagon (from 0.3 to $1000 \mathrm{ng} / \mathrm{ml}$ ) at $20^{\circ} \mathrm{C}$ for $30 \mathrm{~min}$. Each point represents the mean of data obtained with hepatocytes of five different rats binding to isolated hepatocytes of glucagon-treated rats compared with controls was observed over the range of 0.3 to $1000 \mathrm{ng} / \mathrm{ml}$. Parallel Scatchard curves were again obtained $(p>0.05)$. A different total number of binding sites $(p<0.02)$ between the hepatocytes of control $\left(0.70 \pm 0.05 \mathrm{ng} / 10^{6}\right.$ cells $)$ and glucagon-treated rats $\left(0.47 \pm 0.04 \mathrm{ng} / 10^{6}\right.$ cells $)$ was found.

As shown in Figure 6 the degradation of ${ }^{125} \mathrm{I}$ glucagon by the hepatocytes of control and glucagontreated rats, when incubated at $10^{\circ} \mathrm{C}$ and $20^{\circ} \mathrm{C}$, was similar during the $90 \mathrm{~min}$ of incubation $(p>0.05)$, with all values higher at $20^{\circ} \mathrm{C}$.

As shown in Figure 7, the stimulation of cyclic AMP production by glucagon in both populations of hepatocytes was a function of hormone concentrations. In addition, the concentrations of glucagon giving half-maximal $\left(2 \times 10^{-9} \mathrm{~mol} / \mathrm{l}\right)$ or maximal $\left(10^{-7} \mathrm{~mol} / \mathrm{l}\right)$ effects were the same in both groups. However, smaller responses were obtained with the hepatocytes from glucagon-treated rats (control versus G-40 at $10^{-10}$ and $5 \times 10^{-10} \mathrm{~mol} / 1$ of glucagon, $p<0.05$; at $10^{-8}$ and $10^{-7} \mathrm{~mol} / \mathrm{l}, p<0.02$ and at $\left.10^{-9} \mathrm{~mol} / \mathrm{l}, p<0.01\right)$. Isolated hepatocytes of glucagon-treated rats had a proportionate reduction $(33 \%-43 \%)$ of glucagon-stimulated production of cyclic AMP and of the number of glucagon receptors. Under basal conditions, glucose production by the hepatocytes of control and glucagon treated rats was similar at any time of incubation $(p>0.05$, Table 2$)$. Nevertheless, in the presence of glucagon $\left(5.5 \times 10^{-7} \mathrm{~mol} / \mathrm{l}\right)$, the glucose release by hepatocytes of glucagon pre-treated rats was significantly decreased compared with glucose release by cells of control animals (controls versus G-40 at $60 \mathrm{~min}, p<$ 


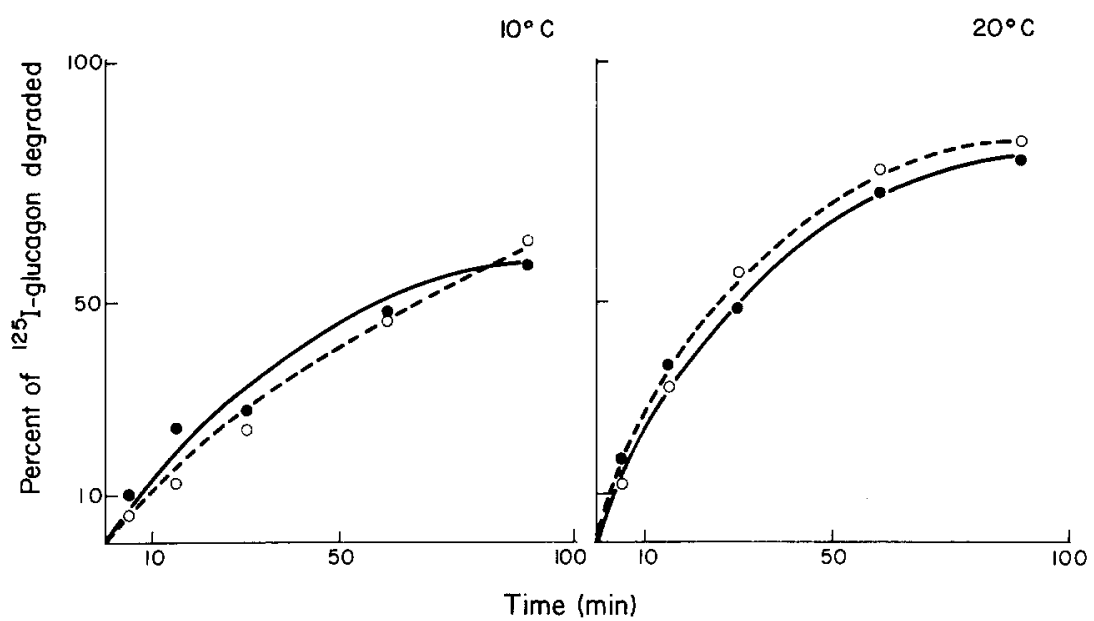

Fig. 6. Degradation of glucagon by isolated hepatocytes. ${ }^{125} \mathrm{I}$-glucagon $\left(1 \times 10^{-10} \mathrm{~mol} / \mathrm{l}\right)$ was incubated with Krebs Ringer bicarbonate $(\mathrm{pH} 7.4)$, containing albumin $(10 \mathrm{~g} / 1)$ and hepatocytes $\left(10^{6} \mathrm{cells} / \mathrm{ml}\right)$ of control $(-)$ and glucagon-treated rats $(40 \mu \mathrm{g} / 100 \mathrm{~g}$ body weight per $8 \mathrm{~h}) .(\mathrm{O} \quad \mathrm{O})$ for the times indicated at $10^{\circ} \mathrm{C}$ or $20^{\circ} \mathrm{C}$. The supernatant was then removed and the percentage of counts that bound to liver membranes during a subsequent incubation at $20^{\circ} \mathrm{C}$ for $90 \mathrm{~min}$ was determined. Vials incubated under identical conditions without cells in the first incubation served as controls. The percentage of hormone degraded was calculated, as a function of the controls, by comparing the percentage of counts of ${ }^{125} \mathrm{I}$-glucagon that bound to isolated hepatocytes during the first incubation and after the second incubation with liver membranes. Each value represents the mean of the data obtained with hepatocytes of three differents rats. Percentage of variation interassay ranges from 1 to 5

0.05 ; at $90 \mathrm{~min}, p<0.05$; at $120 \mathrm{~min}, p<0.025$ ). In addition, the differences between glucagon-stimulated and basal glucose production by hepatocytes of control rats were statistically significant at $60 \mathrm{~min}$ $(p<0.05), 90 \min (p<0.05)$ and $120 \min (p<0.025)$, but no statistically significant differences were observed when the hepatocytes of rats pre-treated with glucagon were incubated in the absence or presence of the hormone $(p>0.05)$. However when cyclic $\operatorname{AMP}(0.8 \mathrm{mmol} / \mathrm{l})$ was added to the incubation medi$\mathrm{um}$, the glucose production increased to the same or even greater concentrations than that observed in non-treated animals (Table 3 ).

When the hepatocytes of control rats were pre-incubated in the absence of glucagon (Table 4), the binding of ${ }^{125} \mathrm{I}$-glucagon to these cells increased markedly in relation to the initial binding. Conversely, pre-incubation of hepatocytes during $4 \mathrm{~h}$ with glucagon $\left(4 \times 10^{-8} \mathrm{~mol} / \mathrm{l}\right)$ produced a decrease $(30 \%)$ in the binding of ${ }^{125} \mathrm{I}$-glucagon to these cells, which was more marked $(39 \%-43 \%)$ after $6 \mathrm{~h}(p<0.05)$ or $8 \mathrm{~h}$ $(p<0.05)$ of pre-incubation. Acute exposure of hepatocytes to glucagon $(2 \mathrm{~h})$ was without effect $(p>$ $0.05)$.

\section{Discussion}

Receptor regulation occurs in many human and animal tissues and is important for the biological activity of hormones as it serves to regulate target cell sensitiv-

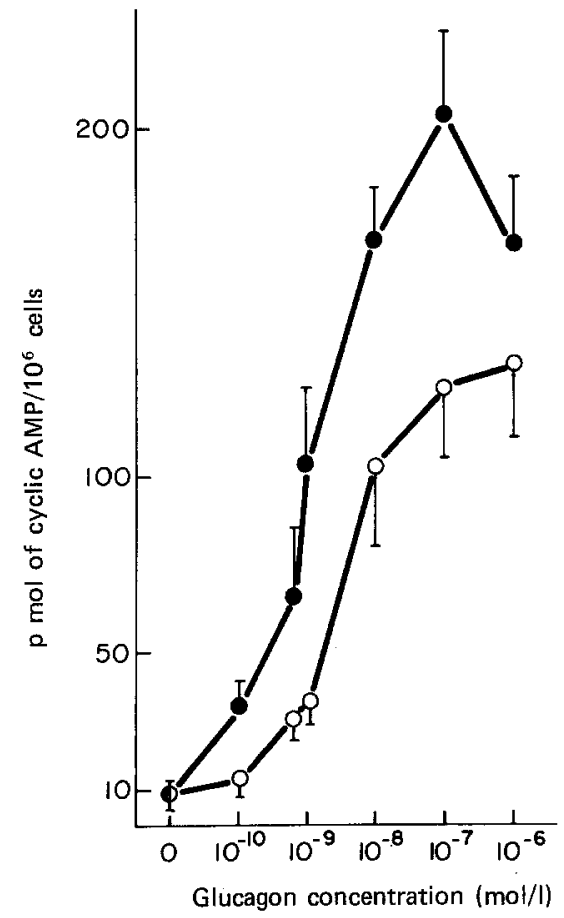

Fig. 7. Glucagon-stimulated cyclic AMP production by isolated hepatocytes of control (-) and glucagon-treated rats $(40 \mu \mathrm{g} / 100 \mathrm{~g}$ body weight per $8 \mathrm{~h})(\mathrm{O} \quad \mathrm{O})$. Liver cells $\left(2 \times 10^{6} \mathrm{ml}\right)$ were incubated for $2.5 \mathrm{~min}$ at $37^{\circ} \mathrm{C}$ with Krebs Ringer bicarbonate ( $\mathrm{pH} 7.4$ ), containing $40 \mathrm{~g} / 1$ defatted albumin, $10 \mathrm{mmol} / \mathrm{l}$ alanine, $2 \mathrm{mmol} / 1$ theophylline and in the absence or presence of glucagon. Each value represents the mean \pm SEM of data obtained with hepatocytes of five different rats. Statistical comparisons between control and $\mathrm{G}-40$ at $10^{-10}$ and $5 \times 10^{-10} \mathrm{~mol} / 1$ of glucagon, $p<0.05 ;$ at $10^{-8}$ and $10^{-7} \mathrm{~mol} / 1, p<$ 0.02 and at $10^{-9} \mathrm{~mol} / 1, p<0.01$ 
Table 2. Glucagon-stimulated glucose production by isolated hepatocytes of control and glucagon-treated rats $(40 \mu \mathrm{g} / 100 \mathrm{~g}$ body weight per $8 \mathrm{~h}$ )

\begin{tabular}{|c|c|c|c|c|c|}
\hline & \multicolumn{5}{|c|}{ Time of incubation (min) } \\
\hline & 15 & 30 & 60 & 90 & 120 \\
\hline & \multicolumn{5}{|c|}{$\mu \mathrm{g}$ Glucose $/ 10^{6}$ Cells } \\
\hline \multirow{4}{*}{$\begin{array}{l}\text { Control rats } \\
\text { Basal } \\
\text { Plus glucagon } \\
\left(5.5 \times 10^{-7} \mathrm{~mol} / 1\right) \\
p \text { (basal versus } \\
\text { glucagon) }\end{array}$} & & & & & \\
\hline & $11 \pm 2$ & $24 \pm 2$ & $49 \pm 2$ & $69 \pm 4$ & $90 \pm 6$ \\
\hline & $14 \pm 2$ & $31 \pm 4$ & $64 \pm 4$ & $91 \pm 6$ & $127 \pm 10$ \\
\hline & NS & NS & $<0.05$ & $<0.05$ & $<0.025$ \\
\hline \multicolumn{6}{|c|}{ Glucagon treated rats } \\
\hline $\begin{array}{l}\text { Basal } \\
\text { Plus glucagon }\end{array}$ & $12 \pm 1$ & $23 \pm 2$ & $42 \pm 4$ & & \\
\hline & $15 \pm 1$ & $28 \pm 3$ & $49 \pm 2^{a}$ & $66 \pm 5^{\mathrm{a}}$ & $82 \pm 6^{b}$ \\
\hline glucagon) & NS & NS & NS & NS & NS \\
\hline \multicolumn{6}{|c|}{$\begin{array}{l}\text { Liver cells }\left(2 \times 10^{6} / \mathrm{ml}\right) \text {, obtained from } 24 \text {-h starved rats, were incu- } \\
\text { bated at } 37^{\circ} \mathrm{C} \text { with Krebs Ringer bicarbonate }(\mathrm{pH} 7.4) \text {, containing } \\
40 \mathrm{~g} / \mathrm{l} \text { defatted albumin, } 10 \mathrm{~mol} / \mathrm{l} \text { alanine in presence or absence of } \\
\text { glucagon. Aliquots }(0.8 \mathrm{ml}) \text { of incubation medium were taken at the } \\
\text { indicated times. Each point represents the mean } \pm \text { SEM of the data } \\
\text { obtained with hepatocytes of seven different rats. Statistical com- } \\
\text { parisons of the glucose release by hepatocytes of control and glu- } \\
\text { cagon pre-treated rats when they were incubated in the presence of } \\
\text { the hormone: }{ }^{a} p<0.05 .{ }^{b} p<0.025 \mathrm{NS}=\text { not significant }\end{array}$} \\
\hline
\end{tabular}

Table 3. Cyclic AMP-stimulated glucose production by isolated hepatocytes of control and glucagon-treated rats $(40 \mu \mathrm{g} / 100 \mathrm{~g}$ body weight per $8 \mathrm{~h}$ )

\begin{tabular}{lccccc}
\hline \multicolumn{5}{c}{ Time of incubation (min) } \\
\cline { 2 - 6 } & 15 & 30 & 60 & 90 & 120 \\
& $\mu \mathrm{g}$ Glucose per $10^{6}$ Cells & & \\
\hline $\begin{array}{l}\text { Control rats } \\
\text { Basal }\end{array}$ & $9 \pm 2$ & $22 \pm 6$ & $45 \pm 10$ & $78 \pm 22$ & $105 \pm 26$ \\
$\begin{array}{l}\text { Plus cyclic AMP } \\
(0.8 \text { mmol/1) }\end{array}$ & $15 \pm 1$ & $30 \pm 7$ & $57 \pm 9$ & $111 \pm 27$ & $130 \pm 27$ \\
$\begin{array}{l}\text { Glucagon treated rats } \\
\text { Basal }\end{array}$ & $19 \pm 3$ & $33 \pm 5$ & $60 \pm 11$ & $70 \pm 19$ & $94 \pm 17$ \\
$\begin{array}{l}\text { Plus cyclic AMP } \\
(0.8 \text { mmol/1) }\end{array}$ & $25 \pm 4$ & $44 \pm 7$ & $79 \pm 12$ & $88 \pm 5$ & $114 \pm 6$
\end{tabular}

Liver cells $\left(2 \times 10^{6} / \mathrm{ml}\right)$, obtained from 24 -h starved rats, were incu-

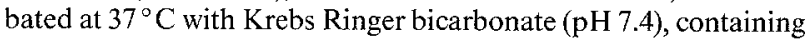
$40 \mathrm{~g} / 1$ defatted albumin, $10 \mathrm{mmol} / 1$ alanine in presence or absence of cyclic AMP. Aliquots $(0.8 \mathrm{ml})$ of incubation medium were taken at the indicated times. Each point represents the mean $\pm S E M$ of data obtained with hepatocytes of three different rats

ity. Hormones may produce changes in their own receptor number or changes in receptors for other hormones. Hormone-dependent receptor regulation has been decribed for catecholamines, steroids, glycoproteins and peptide hormones [1-4].

Although liver glucagon receptor concentrations change under different physiopathological situations,
Table 4. Effect of pre-incubation with glucagon on ${ }^{125} \mathrm{I}$-glucagon binding to isolated hepatocytes of control rats

\begin{tabular}{llll}
\hline $\begin{array}{l}\text { Time of } \\
\text { pre-incubation } \\
\text { (h) }\end{array}$ & \multicolumn{3}{l}{${ }^{125} \mathrm{I}$-Glucagon bound (fmol/10 cells) } \\
\cline { 2 - 4 } & Without glucagon & $\begin{array}{l}\text { With glucagon } \\
\left(4 \times 10^{-8} \mathrm{~mol} / \mathrm{l}\right)\end{array}$ & $p$ \\
\hline 0 & $3.4 \pm 0.3$ & $3.4 \pm 0.3$ & $>0.05$ \\
2 & $3.7 \pm 0.3$ & $4.1 \pm 0.5$ & $>0.05$ \\
4 & $4.1 \pm 0.3$ & $2.9 \pm 0.4$ & $\simeq 0.05$ \\
6 & $4.1 \pm 0.5$ & $2.5 \pm 0.4$ & $<0.05$ \\
8 & $4.2 \pm 0.5$ & $2.4 \pm 0.4$ & $<0.05$ \\
\hline
\end{tabular}

Liver cells $\left(2 \times 10^{6} / \mathrm{ml}\right)$, obtained from 24 -h starved rats, were incubated with 199 medium, albumin $(20 \mathrm{~g} / \mathrm{l})$, penicillin $(2000 \mathrm{U})$ and streptomycin $(2 \mathrm{mg} / \mathrm{ml})$ in the absence or presence $\left(4 \times 10^{-8} \mathrm{~mol} / \mathrm{l}\right)$ of glucagon. At the indicated times, aliquots of the incubation medium were taken. Unlabelled glucagon was dissociated by washing and incubating cells at $37^{\circ} \mathrm{C}$ for $30 \mathrm{~min}$. Cell viability remained constant throughout the $8 \mathrm{~h}$ of incubation. Each point represents the mean \pm SEM of data obtained with hepatocytes of eight different rats. Statistical comparisons were carried out with data obtained in the absence or presence of glucagon

at present there is contradictory evidence about a glucagon-dependent regulation of these receptors. Since most of these studies were carried out in vivo and, under these circumstances, both endogenously and exogenously-induced hyperglucagonaemia are associated with marked changes of other hormones or metabolites, clear-cut evidence of a direct hormonal effect could not be obtained. In an attempt to elucidate the role of glucagon on its hepatic receptors, we have designed a model in which both exposure in vivo and in vitro to the hormone were achieved. A persistent hyperglucagonaemia in vivo was induced by injecting repeatedly a long-acting glucagon preparation, avoiding the undesirable rebound effects provoked by the administration of soluble crystalline glucagon. The amount of glucagon injected was adjusted in such a manner that the resulting glucagon concentrations in plasma were close to the physiological level.

The recovery of plasma liver membrane protein and marker enzyme activities indicate that there were no significant differences in the membrane purification procedure followed with the groups of rats that comprise the present study. Decreased ${ }^{125}$ I-glucagon binding to liver membranes of glucagon-treated rats reflects a decrease in the number of glucagon receptors. Comparison of the Scatchard curves at the same degree of fractional saturation indicates that the apparent affinities were the same, with the major alteration being the decrease in receptor concentration. However, ${ }^{125}$ I-insulin binding to liver membranes of control and glucagon-treated rats was the same, suggesting a specific role for glucagon. Studies of the kinetic properties of the glucagon receptor of control and glucagon-treated rats revealed that association 
rates were indistinguishable. Furthermore, the degradation of glucagon and glucagon receptors was identical in glucagon-treated and control groups of rats, suggesting that the observed changes in glucagon binding do not appear to be related to alterations in glucagon degradation by the liver membranes or by a different stability of the receptor during the incubation periods.

The interactions between glucagon and its receptor were studied in isolated hepatocytes in an attempt to eliminate possible changes in receptor properties and in the composition of plasma cell fractions originating during the isolation procedure [26]. By these experiments we established that qualitative and quantitative properties of glucagon-receptor interactions of both experimental groups of rats were identical from isolated hepatocytes and plasma liver membranes.

Since alterations in hormone binding and hormone action are not always parallel, comprehensive analysis of the binding data in isolated hepatocytes can be gained with simultaneous measurement of the biological response to glucagon. This analysis is important since the glucagon receptor population may be heterogenous [27] and also because some binding sites may not necessarily lead to an ultimate biological response. Thus, Birnbaumer and Pohl [28] have reported that binding to only $20 \%$ of glucagon receptors is sufficient to obtain a maximal hormonal response. However, the results reported in this study indicate that the reduced number of glucagon receptors in hepatocytes from glucagon-treated rats was proportional to the diminished cyclic AMP and glucose production induced by this hormone.

From the data obtained both with liver membranes and isolated hepatocytes, we can assume that the reduced response to glucagon by the cells of rats treated with this hormone is fully accounted for by the decreased concentrations of the glucagon receptors which are otherwise normal according to the functional criteria discussed above.

This statement was reinforced by the fact that hepatocytes of control rats, when cultured in the presence of glucagon, showed a loss of binding sites for this hormone, indicating a direct effect of glucagon in their receptor concentrations. The decrease of binding sites for glucagon cannot be accounted for by a contamination of the receptor with the glucagon added during the pre-incubation period, since this effect was not observed during the first $2 \mathrm{~h}$ of treatment with glucagon $4 \times 10^{-8} \mathrm{~mol} / \mathrm{l}$. Furthermore, the hormone dissociation procedure followed, and the subsequent washing of the hepatocytes proved to be good enough for removing unlabelled glucagon from these cells.
Possible mechanisms involved in the reduction of glucagon receptors by the homologous hormone could be related to: 1 ) decreased synthesis;2) modified subunit or storage pools; or 3 ) activated degradation of the receptor. Thus, the amount of a given membrane protein seems to be a consequence of an equilibrium between synthesis and degradation [29] and these activities can be modified under different physiological situations [30]. As has been reported [4,31], down regulation of insulin and growth hormone receptors is related more to an increased degradative rate of their receptors than to a decreased biosynthesis.

Since glucagon has powerful catabolic properties, the existence of a down regulation mechanism could protect target cells from undesirable effects. This seems likely to occur in pathophysiological situations, such as starvation, development and liver regeneration. In fact, all these circumstances have in common hyperglucagonaemia co-existing with a reduced number of glucagon binding sites and decreased activity of glucagon-stimulated adenylate cyclase. The same criteria could be applied to the apparent evanescence of glucagon's biological activity observed in non-diabetic animals [32] and man [33] during the constant infusion of glucagon. However, on the other hand, not every situation of hyperglucagonaemia results in the same fall in glucagon receptor concentrations, probably because other factors or metabolic disturbances can be opposed to the effect of glucagon on their receptors.

Acknowledgments. The authors wish to thank Dr. M. Serrano Rios for his critical reading of the manuscript and Ms S. Pastor for her assistance. This work has been supported by grant from Fundación Rodriguez Pascual and Comisión Asesora para el Desarrollo de la Investigación and Pfizer España Laboratories.

\section{References}

1. Gavin JR, Roth J, Neville DM Jr, De Meyts P, Buell DN (1974) Insulin-dependent regulation of Insulin receptor concentrations. A direct demonstration in cell culture. Proc Natl Acad Sci USA 71: 84-88

2. Mukherjee C, Caron MG, Lefkowith RJ (1975) Catecholamineinduced subsensitivity of adenylate cyclase associated with loss of B-adrenergic receptor binding sites. Proc Natl Acad Sci USA 72: 1945-1949

3. Hinkle PM, Tashjian AH (1975) Thyrotropin-releasing hormone regulates the number of its own receptors in the $\mathrm{GH}_{3}$ strain of pituitary cells in culture. Biochemistry 14: 2845-3851

4. Lesniak MA, RothJ (1976) Regulation of receptor concentration by homologous hormone. Effect of human growth hormone on its receptor in IM-9 lymphocytes. J Biol Chem 251: 3720-3729

5. Fouchereau-Peron M, Rancon F, Freychet P, Rosselin G (1976) Effect of feeding and fasting on early steps of glucagon action in isolated rat liver cells. Endocrinology 98: 755-760 
6. BlazquezE, Rubalcava B, Montesano R, Orci L, UngerRH (1976) Development of insulin and glucagon binding and the adenylate cyclase response in liver membranes to the prenatal, postnatal, and adult rat: Evidence of glucagon 'resistance'. Endocrinology 98: $1014: 1023$

7. Leffert HL, Koch KS, Rubalcava B, SellS, MoranT, Boorstein $R$ (1978) Hepatocyte growth control: in vivo approach to problems of liver regeneration and function. J Natl Cancer Inst 48: 87-101

8. Soman V, Felig P (1977) Glucagon and insulin binding to liver membranes in a partially nephrectomized uremic rat model. $\mathrm{J}$ Clin Invest 60:224-232

9. Soman V, Felig P (1978) Glucagon binding and adenylate cyclase activity in liver membranes from untreated and insulintreated diabetic rats. J Clin Invest $61: 552-560$

10. BhathenaSJ, Voyles NR, SmithS, RecantL (1978) Decreased glucagon receptors in diabetic rat hepatocytes. Evidence for regulation of glucagon receptors by hyperglucagonemia. J Clin Invest 61: 1488-1497

11. Soman V, Felig P (1978) Regulation of the glucagon receptor by physiological hyperglucagonemia. Nature 272:829-832

12. SrikantCB, Freeman D, McCorkle K, Unger RH (1977) Binding and biologic activity of glucagon in liver cell membranes of chronically hyperglucagonemia rats. J Biol Chem 252: 7434-7436

13. Faloona GR, Unger RH (1974) Glucagon. In: Jaffe BM, Behrman HR (eds) Methods of hormone radioimmunoassay. Academic Press, New York, pp 317-330

14. Neville DM Jr (1968) Isolation of an organ specific protein antigen from cell-surface membrane of the rat liver. Biochim Biophys Acta 154:540-552

15. Pohl SL, Birnabaumer L, Rodbell M (1971) The glucagon-sensitive adenyl cyclase system in plasma membranes of rat liver. I Properties, J Biol Chem 246: 1849-1856

16. Avruch J, Wallach DFH (1971) Preparation and properties of plasma membrane and endoplasmic reticulum fragments from isolated rat fat cells. Biochim Biophys Acta 233:334-347

17. Lowry OH, Rosebrough NJ, Farr AL, Randall RJ (1951) Protein measurement with the folin phenol reagent. J Biol Chem 193: 265-275

18. Gomez Acebo J, Lopez QuijadaC, CandelaJLR (1966) Fine structure of the $\beta$-cell from pancreas pieces incubated in vitro. Diabetologia 2: $110-118$

19. Williamson JR, Corkey BE (1969) Assays of intermediates of the citric acid cycle and related compounds by fluorometric enzyme methods. Methods in Enzymology 13: 434-513

20. Nottey JJ, Rosselin G (1971) Monoiodo glucagon: preparation, isolement, identification, controle radio-immunologique. CR Acad Sci (Paris) 273:2218-2121

21. Rubalcava B, Rodbell M (1973) The role of acidic phospho- lipids in glucagon action on rat liver adenylate cyclase. J Biol Chem 248: 3831-3837

22. Guillory RJ, RackerE (1968) Oxidative phosphorylation in brown adipose mitochondria. Biochim Biophys Acta 153: $490-493$

23. Huggett ASG, Nixon DA (1957) Use of glucose oxidase, peroxidase and 0 -dianisidine in determination of blood and urine glucose. Lancet 2: 273, 368-370

24. Steiner AL, Kipnis DM, Utiger R, ParkerC (1969) Radioimmunoassay for the measurement of adenosine $3^{\prime}, 5^{\prime}$-cyclic phosphate. Proc Natl Acad Sci 64: 367-373

25. Botham KM, Boyd GS (1979) Cholesterol 7-hydroxylase in isolated rat liver cells. Eur J Biochem 95: 533-542

26. Chang KJ, Bennett V, Cuatrecasas P (1975). Membrane receptors as general markers for plasma membrane isolation procedures (the use of $\mathrm{I}^{125}$ labeled wheat germ aglutinin, insulin and cholera toxin). J Biol Chem 250: 488-500

27. Sonne O, Berg T, Christoffersen T (1978) Binding of ${ }^{125}$ I-labeled glucagon and glucagon-stimulated accumulation of adenosine 3', 5'-monophosphate in isolated intact rat hepatocytes. Evidence for receptor heterogeneity. J Biol Chem 253: 3203-3210

28. Birnbaumer L, PohlSL (1973) Regulation of glucagon-specific binding sites to glucagon-dependent stimulation of adenyl cyclase activity in plasma membranes of rat liver. J Biol Chem 248: 2056-2061

29. Schimke RT (1975) Turnover of membrane proteins in animal cells. In: Korn ED (ed) Methods in membrane biology, vol3. Plenum Press, New York, pp 201-236

30. Berlin CM, Schimke RT (1965) Influence of turnover rates on the responses of enzymes to cortisone. Mol Pharmacol 1: 149-156

31. Kosmakos FC, Roth J (1976) Cellular basis of insulin-induced loss of insulin receptors. 58th Annual Meeting of the Endocrine Society, p69 (Abstract)

32. Cherrington AD, Vranic M (1974) Effect of interaction between insulin and glucagon on glucose turnover and FFA concentration in normal and depancreatized dogs. Metabolism 23: 729-744

33. Felig P, Wahren J, Hendler R (1976) Influence of physiologichyperglucagonemia on basal and insulin-inhibited splanchnic glucose output in normal man. J Clin Invest 58: 761-765

Received: 26 June 1980

and in revised form: 17 November 1981

Dr. Enrique Blázquez

Departamento de Fisiología

Facultad de Medicina

Universidad de Oviedo

Oviedo, Spain 